Article

\title{
An Exploration of the Critical Risk Factors in Sustainable Telecom Services: An Analysis of Indian Telecom Industries
}

\author{
Wen-Kuo Chen ${ }^{1}$, Venkateswarlu Nalluri ${ }^{2}$, Suresh $\mathrm{Ma}^{3}$, Mei-Min Lin ${ }^{4}$ and Ching-Torng Lin ${ }^{2, *}$ \\ 1 College of Management, Chaoyang University of Technology, Taichung 413310, Taiwan; wkchen@cyut.edu.tw \\ 2 College of Management, Da-Yeh University, Changhua 51591, Taiwan; nallurivenkey7@gmail.com \\ 3 Amrita School of Business, Amrita Vishwa Vidyapeetham University, Coimbatore 641112, India; \\ msuresh@cb.amrita.edu \\ 4 Department of Finance, National Changhua University of Education, Changhua 50074, Taiwan; \\ vp@sanyeu.com.tw \\ * Correspondence: charllin@mail.dyu.edu.tw
}

Citation: Chen, W.-K.; Nalluri, V.; Ma, S.; Lin, M.-M.; Lin, C.-T. An Exploration of the Critical Risk Factors in Sustainable Telecom Services: An Analysis of Indian Telecom Industries. Sustainability 2021, 13, 445. https://doi.org/ $10.3390 /$ su13020445

Received: 26 November 2020 Accepted: 28 December 2020 Published: 6 January 2021

Publisher's Note: MDPI stays neutral with regard to jurisdictional clai$\mathrm{ms}$ in published maps and institutional affiliations.

Copyright: (C) 2021 by the authors. Licensee MDPI, Basel, Switzerland. This article is an open access article distributed under the terms and conditions of the Creative Commons Attribution (CC BY) license (https:// creativecommons.org/licenses/by/ $4.0 /)$.

\begin{abstract}
Different sources of risk factors can occur in sustainable supply chain management due to its complex nature. The telecommunication service firm cannot implement multiple improvement practices altogether to overcome the risk factors with limited resources. The industries should evaluate the relationship between risk factors and explore the determinants of improvement measures. The purpose of the present study is to identify and analyze critical risk factors (CRFs) for enhancing sustainable supply chain management practices in the Indian telecommunication industry using interpretive structural modelling (ISM). Risk factors are identified through a literature survey, and then with the help of experts, nine CRFs are identified using a fuzzy Delphi method (FDM). The relationship among these CRFs has been analyzed using ISM, and the driving and the dependence power of those CRFs are analyzed. Results indicate that both "government policies (laws and regulations)" and "the impact of rapid change in technology" are independent or key factors that affect the sustainability of the telecommunications supply chain. In addition, results provide significant managerial implications, including enhanced sustainability, and the government should build justice, fairness, open laws, certainties, and regulations to prevent risk in the telecommunications industry supply chain; service providers should monitor the rapidly evolving technologies and focus on technical learning and organizational capacity development to overcome the impact of technological changes. The contribution of this study is using a novel approach to establish a hierarchical structural model for an effective understanding of CRFs relationships and to explore decisive risk factors that can help telecom service providers to better plan and design effective improvement strategies to enhance sustainability supply chain management.
\end{abstract}

Keywords: sustainability supply chain management; critical risk factors (CRFs); fuzzy Delphi method (FDM); telecommunications industry; interpretive structural modelling (ISM)

\section{Introduction}

In India, with the announcement of the new economic policy in July 1991, the telecommunication sector declared itself open to private companies [1]. The entry of private companies in the sector required more regulation. Consequently, the Telecommunications Regulatory Authority of India (TRAI) was established in 1997 to regulate the telecom service providers [2-4]. The TRAI issued a number of regulations to transform the monopolistic telecommunication market into a competitive market, making it open to more private service providers [5]. Therefore, sustainability supply chain management is defined as the systematic integration of key business processes to improve the short- and long-term performance of individual companies [6] and their supply chains; moreover, to the achievement of economic, social, and environmental goals [7]. 
Moreover, the telecommunication companies are increasingly focused on profitability and rapid growth due to fast-growing technologies and high competition within the industry [8]. These developments can have a serious impact on people and society. In addition, the supply chain goals are integrated with suppliers, information flow management, and capital management as well as inter-collaboration with other companies, and social, economic, and environmental dimensions of risk affects the sustainability [9]. However, the telecommunication supply chain is associated with a few risk factors, related to public health and safety. At the same time, the telecommunication supply chain is associated with the environment, and uncertainty poses serious risks and challenges to the service providers [10]. Therefore, it is clear that telecom companies are willing to take sustainable measures [11]. Especially in developing countries, economic, safety, and health precautions in telecommunications supply chain operations are often limited, which creates problems. For example, all telecommunication company's stock prices declined due to $2 \mathrm{G}$ and $3 \mathrm{G}$ scams. That not only influenced companies involved in $2 \mathrm{G}$ and $3 \mathrm{G}$ scams, but also those companies that are not involved in either scams. Furthermore, the investors lost confidence in the entire telecommunication sector due to those scams [12]. In another case, regarding human health, according to the Environmental Protection Agency (EPA) report-2018, the radiation signals during voice calls and messages through the air can accumulate in the human body and negatively influence the nervous system, and can cause a significant risk for present and next generation humans. The demand uncertainty is another key feature of service supply chain [13]. In addition, an uncertain market and short life-cycle services are major issues in predicting reliable forecasts of the potential capacity requirement in the telecommunication sector [14]. Companies have taken some steps to manage these types of risks from different dimensions [9]. Most of the sustainable risk factors are often correlated in practice. For example, environmental issues such as radiofrequency levels in the air can damage human health, they can lead to impacting a company's reputation, resulting in decreased sales and revenue, and affecting brand strength and cash flow. Those kinds of risks can influence the interactions among supply chain practices.

In the present literature, there has been growing interest in sustainable supply chain management (SSCM) and risk management. Several researchers have studied SSCM in the telecommunication sector $[15,16]$. Among them, few scholars have analyzed the environmental risk in SSCM [17,18]. In addition, most of the previous studies have rarely analyzed sustainable risk issues in the supply chain [19] and have seldom integrated sustainable issues into the existing supply chain management and risk management literature [20]. In addition, few other existing studies focus on individual risk dimensions [21,22]. This can lead to the problem of under-optimization and the danger of misleading implications in management [23]. Moreover, the preventive measures often affect each other due to the dynamic nature of risk factors in the telecommunications supply chain [17]. Therefore, the applicability of remedies and preventive actions is needed to guide managers and policymakers to gain a holistic view of their preventive actions to control these risk factors for the sustainability of supply chain. In addition, telecommunication companies cannot implement multiple supply chain improvement practices together to compete with risk factors with limited resources. It is necessary to establish mutual relationships among risk factors and to discover decisive risk factors for improvement. Based on the above literature review, this study focuses on several research objectives, summarized as:

- To discover critical risk factors (CRFs) associated with a supply chain using the fuzzy Delphi method (FDM) for the telecommunication industry.

- To assess the interrelationships among CRFs.

- To identify and establish the hierarchical structural model of CRFs to offer guidelines for designing an effective preventive measure plan for the telecommunication industry.

Based on the above considerations, the present study begins with the identification of risk factors that are derived from the most recent literature. To confirm risk factor, a set of questionnaires is prepared and discussed with decision-makers. After that, the authors performed the FDM to find the CRF's with help of the expert's assessment from different 
public and private telecom companies in India $[24,25]$. In addition, an effort is made to observe the in-depth relationship between CRFs for sustainable operations in the telecommunication service supply chain, through the interpretive structural modelling (ISM) approach. In fact, ISM is an interactive learning tool that can identify the direct and transitive relationships among factors in a particular problem. ISM is primarily considered as a group learning method, but it can also be used alone. It has been extensively applied to discover barriers and to analyze success and failure factors in various fields [26-28]. Following, the ISM and impact matrix cross-reference multiplication applied to a classification (MICMAC) analysis was employed to examine the interrelationships, driving and dependence power, and develop a hierarchical structural model of the CRFs.

The results show that "government policies (laws and regulations)", "new entering companies", "impact of rapid change of technology", and "difficulty in import technology and process" are the most affecting CRFs of sustainable operations in telecommunication supply chain. "Lack of telecom infrastructure in semi-rural areas", "change customer expectations", and "market competition" are the linkage risk factors. In addition, "illegal activities (e.g., 2G scams), and "environmental pollution" are indirectly affecting supply chain sustainability. The primary contribution of this study is providing a comprehensive understanding of contextual relationships and hierarchical structural model among CRFs of supply chain sustainability in telecommunication sector. It will improve the understanding of essential risk factors and importance of the CRFs to achieve sustainable operations within supply chain of telecommunication companies in developing countries. Thereby, the hierarchical structural model will be providing most affecting CRFs, and it will guide the telecommunication company's managers and policy makers to effectively develop strategies with limited resources. Furthermore, this research aimed to analyze ranking CRFs with MICMAC, it would help telecom service providers and managers to take effective preventive measures in their supply chain.

The rest of the paper is organized as follows. Section 2 deals with the literature review. Section 3 presents an overview of the research methodology and the demonstration of the current study using ISM is presented in this section. Section 4 presents the findings and discussion. In Section 5, the conclusion in addition to future research directions and final limitations are given.

\section{Literature Review}

In this section, the literature review has been done four-fold: the sustainability in the supply chain, supply chain sustainability in telecommunication companies, research gap and identification of risk factors.

\subsection{Sustainability in Supply Chain}

Sustainable supply chain management (SSCM) is the integration of sustainable development and SCM. Whereby sustainable development is described as having certain dimensions such as economic, social, and environmental issues for human development, which also affect the supply chain and long-term strategies of companies, while the SCM is considered to be new, and a great interest in sustainable SCM has been growing rapidly over the past decade [29]. Therefore, innovative market, government policies, and growing awareness have encouraged companies to integrate sustainable approaches into their supply chain operations to improve the overall performance and to gain a competitive advantage in the emerging market [30,31]. Few studies have examined the extent to which the supply chain sustainability level can be enhanced through strategic alliances and buyer-supplier relationships [15,32]. Moreover, there are many examples in the current business system of realizing the risk factors arising from a complex supply chain [33,34]. Nevertheless, SSCM is gradually becoming a strategic requirement for telecommunication companies [6]. In addition, many risk factors may appear due to the complexity in the supply chain. Unlike traditional SCM, it usually focuses on different environmental, social, and economic risk dimensions, Valinejad and Rahmani [9] claimed that it should include 
two more aspects such as technology and organizations. In addition, the typical risk factors and the sustainability of supply chain bring different risks to the telecommunication company [35]. Moreover, telecommunication companies have been suffering to gain competitive advantage in the market and overall sustainability in their operations throughout supply chain. Therefore, an attempt is made to explore the sustainable CRFs.

\subsection{Supply Chain Sustainability in Telecommunication Companies}

In recent years, telecommunication companies supply chain strategies is changing significantly, due to high competition, rapid technological changes, and uncertainty of the demand levels. According to Song et al. [6], selecting the right supplier, the uncertainty of demand and supply, and the lack of technology are the most affecting risk factors of telecommunication companies' supply chain. In the existing literature, few studies have examined the SSCM risks in the telecommunication service sector [6]. Moreover, those studies have not been fully investigated on sustainable risk factors $[36,37]$. Especially, telecommunication sector in India. In SSCM literature, the most empirical studies focus on environmental and economic aspects [38,39], and theoretical framework development [40-42].

Based on literature review, it is clear that there have been conducting researches in related areas such as telecom service in rural areas [43], manufacturing resources [44]. Scholars have studied the development of theory [45], development of models [46], and validation of models in addition to the implementation of practices [47,48]. Moreover, few researches has been conducted on barriers, risks, and obstacles that prevail in rural areas and service sectors. And, they were highly suggestive to telecommunication researchers and professionals for future research studies [27,49]. Although the telecommunication service sector has been grown rapidly to be one of the most innovative and highly developing sectors. These developments are increasingly dependent on business and social aspects while rapid technological change and the importance of delivering services in this industry generate uncertainties and challenges for achieving sustainability of supply chain. In the present literature, almost no study is conducted on CRFs identification and the interrelationship among CRFs in the context of supply chain sustainability within or outside India.

\subsection{Research Gap}

Few studies have been conducted on the sustainability of the supply chain in developed countries $[16,41,50]$. Moreover, it is clear that there is very few research works focusing on developing countries, especially India. Furthermore, most studies concentrate mainly on strategic factors, drivers, and success, failure factors, and barriers to the adoption of telecom services, and analysis of rural areas in the telecommunications' supply chain $[27,51-54]$. Few other studies have focused on the theoretical framework and the identification of economic, social, and environmental dimensions of risks [35]. And Valinejad and Rahmani [9] have dealt with the technical and institutional risk dimensions, which neither cover all the CRFs, nor analyzes the interrelationships between sustainable risk factors in the supply chain.

However, as per existing literature, there is few studies have emphasizing the interrelationships between risk factors, but they assess the applicability of the proposed method and the effectiveness of telecommunication company products [6]. In addition, few studies analyzed the factors with networking model, and many decision issues cannot be structured than hierarchically because they do not clarify the interaction and dependence of higherlevel factors in a hierarchy of lower-level factors, though it is possible in a hierarchical structure model, which can clarify critical factors. Moreover, the telecommunication supply chain includes different risks and risk factors in every operation and business activity. Evidently, these risks and risk factors would be responsible for causing sustainability in the supply chain, thereby leading to decreased performance $[55,56]$. Therefore, it requires a risk identification and analysis process from an industrial perspective to improve supply chain efficiency [57]. In addition, the topic of risk analysis in the SSCM theory is still unexplored, 
especially in the Indian context [24]. Hence, it is considered a research gap in the supply chain sustainable dimension. This makes supply chain sustainability risk management as an important tool to maintain supply chain and to improve its performance. Moreover, this issue is underrepresented in the existing literatures.

\subsection{Identification of Risk Factors}

The potential consequences of risks can affect the supply chains sustainability of telecommunication companies. Moreover, any attempt to manage it should avoid risk factors and their consequences. A company's corporate strategic objective is to choose which risks incorporating into its supply chain operations. By considering supply chain sustainability as a connection of risks, and to transfer it to the external environment and to improve its value proposition to its customers.

However, only a limited number of research studies have been identified that specifically investigate the risk factors for the sustainability supply chain of the telecommunication industry. Therefore, each research document is carefully examined and the risk factors obtained are described. Based on the frequency of occurrence and the diversification of factors, this study covers the factors of different names and titles that are frequently mentioned in the telecommunication industry. The authors found 18 common risk factors in literature review. Then after, the risk factors conformed by decision makers from telecommunication sector. Therefore, the conformed risk factors are shown in Table 1.

Table 1. Sustainability-related supply chain risks.

\begin{tabular}{|c|c|c|c|}
\hline No. & Risk Factors & Brief Description & Sources \\
\hline $\mathrm{R} 01$ & $\begin{array}{l}\text { Goods and Services Tax } \\
\text { implementation }\end{array}$ & $\begin{array}{l}\text { The implementation of the goods and service tax plays an } \\
\text { important role in the economy through its impact upon } \\
\text { both efficiency and sustainability. }\end{array}$ & [58-62] \\
\hline $\mathrm{R} 02$ & $\begin{array}{l}\text { Foreign direct } \\
\text { investment policy }\end{array}$ & $\begin{array}{l}\text { The Indian telecommunication industry has become very } \\
\text { attractive to foreign investors and, as a result, they need } \\
\text { the right policies. Lack of proper FDI policy from } \\
\text { authorities is a commonly encountered risk factor towards } \\
\text { telecommunication sector. }\end{array}$ & [63-66] \\
\hline $\mathrm{R} 03$ & $\begin{array}{l}\text { Illegal activities } \\
\text { (e.g., 2G scams) }\end{array}$ & $\begin{array}{l}\text { This factor refers to the negative impact of unethical } \\
\text { activities upon the telecom companies. }\end{array}$ & {$[6,12,35,67]$} \\
\hline R04 & $\begin{array}{l}\text { Newly entering companies } \\
\text { (e.g., Reliance JIO } \\
\text { Infocomm Limited) }\end{array}$ & $\begin{array}{l}\text { To understands the impact of unfair business strategy by } \\
\text { new companies entering the market. }\end{array}$ & [68-72] \\
\hline R05 & $\begin{array}{l}\text { Effect of merge Idea and } \\
\text { Vodafone }\end{array}$ & $\begin{array}{c}\text { Merge of idea and vodafone may bring new risks to } \\
\text { shareholders. For example, poor decision-making and } \\
\text { extra time and cost are spent on maintaining sustainability } \\
\text { in the supply chain. }\end{array}$ & {$[69,73-75]$} \\
\hline R06 & $\begin{array}{l}\text { Lack of education and } \\
\text { technical skills }\end{array}$ & $\begin{array}{l}\text { Understanding of sustainable technology and operations } \\
\text { among partners requires a set of technical capabilities in a } \\
\text { consistent and dynamic manner across the supply chain. }\end{array}$ & {$[6,9,76,77]$} \\
\hline $\mathrm{R} 07$ & $\begin{array}{l}\text { Impact of rapid change of } \\
\text { technology }\end{array}$ & $\begin{array}{c}\text { The rapid technological improvements of this factor } \\
\text { constitute a major obstacle to the telecommunication } \\
\text { industry's survival. }\end{array}$ & [78-80] \\
\hline R08 & $\begin{array}{l}\text { Lack of telecom infrastructure } \\
\text { in semi- rural or rural areas }\end{array}$ & $\begin{array}{l}\text { This factor refers to the lack of infrastructure such as } \\
\text { power, road, skilled labor availability and resource } \\
\text { availability in semi-rural or rural areas. }\end{array}$ & {$[6,9,76,77,80-83]$} \\
\hline R09 & $\begin{array}{l}\text { Difficulty in import } \\
\text { technology and process }\end{array}$ & $\begin{array}{l}\text { It refers to the difficulty in effectively reengineering the } \\
\text { existing process when the company imports technology } \\
\text { and it needs to modify the existing process to suit the } \\
\text { technology import. }\end{array}$ & {$[78,80,84,85]$} \\
\hline
\end{tabular}


Table 1. Cont.

\begin{tabular}{|c|c|c|c|}
\hline No. & Risk Factors & Brief Description & Sources \\
\hline R10 & $\begin{array}{l}\text { Impact of Social factors (age, } \\
\text { income and cultural) }\end{array}$ & $\begin{array}{l}\text { The risk factor refers to the benefits of the organization to } \\
\text { the community. It measures social factors such as age, } \\
\text { income and culture. }\end{array}$ & {$[6,9,24,35,76,77,81,86]$} \\
\hline R11 & $\begin{array}{l}\text { Change of customer } \\
\text { expectations }\end{array}$ & $\begin{array}{l}\text { This factor refers to the continuous change in customer } \\
\text { needs and preferences; increase in customer expectations } \\
\text { in the market due to external or internal factors (e.g., } \\
\text { competition and service quality). }\end{array}$ & {$[6,24,77,78,80]$} \\
\hline R12 & $\begin{array}{l}\text { Effect of Corporate Social } \\
\text { Responsibility (CSR) }\end{array}$ & $\begin{array}{l}\text { Making the telecommunication industry to be connected } \\
\text { with its corporate social responsibility would help to } \\
\text { ensure the sustainability of this relationship. }\end{array}$ & [87-91] \\
\hline R13 & $\begin{array}{l}\text { Government policies (laws } \\
\text { and regulations) }\end{array}$ & $\begin{array}{l}\text { This risk factor that prevents the widespread acceptance } \\
\text { of telecommunication services in the Indian market is } \\
\text { further affected by legal and regulatory issues. }\end{array}$ & {$[9,24,64,76,77,80,81,92]$} \\
\hline R14 & Supplier quality issues & $\begin{array}{l}\text { Supplier-side quality issues would affect sustainability of } \\
\text { supply chain efficiency from an industrial perspective. }\end{array}$ & {$[9,64,93,94]$} \\
\hline R15 & Market competition & $\begin{array}{l}\text { Unexpected or incorrect demand forecast; uncertain due } \\
\text { to fierce market competition. }\end{array}$ & {$[6,24,78,79]$} \\
\hline R16 & $\begin{array}{l}\text { Health effects of } \\
\text { electromagnetic radiations }\end{array}$ & $\begin{array}{l}\text { Working under unhealthy conditions and the use of } \\
\text { hazardous substances that threaten human health and } \\
\text { safety in the supply chain. }\end{array}$ & {$[9,90,95,96]$} \\
\hline R17 & $\begin{array}{l}\text { Acts of Nature (e.g., extreme } \\
\text { weather or earthquakes) }\end{array}$ & $\begin{array}{c}\text { Rare, but severe disasters caused by nature (example: } \\
\text { flood, extreme weather or earthquakes). }\end{array}$ & {$[6,35,97,98]$} \\
\hline R18 & Environmental Pollution & $\begin{array}{c}\text { Air, water, soil or other pollution due to facility } \\
\text { operations or services. }\end{array}$ & {$[6,9,24,35,99]$} \\
\hline
\end{tabular}

\section{Research Methodology}

Present study adopted three-phase research flow as shown in Figure 1 to achieve the objectives of this research. In the first phase, the literature is reviewed to quickly identify risk factors that could affect the sustainability of the Indian telecommunication service supply chain. Followed by confirm identified risk factors from different public and private telecom company's decision makers. The decision makers' profile is shown in Table 2. In the second phase, the authors performed the FDM to find the CRF's with help of the decision maker's assessment from telecom companies in India [100]. Nine CRF's are determined based on the threshold value (0.65) of the FDM. We commented decision makers of telecommunication company with a set of questionnaires to analysis interrelationship among CFR's as final phase.

Table 2. Profile of decision makers.

\begin{tabular}{ccc}
\hline Profile & \multicolumn{2}{c}{ Classification } \\
\hline Employer & \multicolumn{2}{c}{ Telecommunication company } \\
Type of the company & Public & Private \\
Number & 13 & 17 \\
Year(s) of experience in the present company & \multicolumn{2}{c}{$>2$ Years } \\
Year(s) of experience within the industry & $>5$ Years \\
Educational qualification & All have Bachelor degree \\
\hline
\end{tabular}




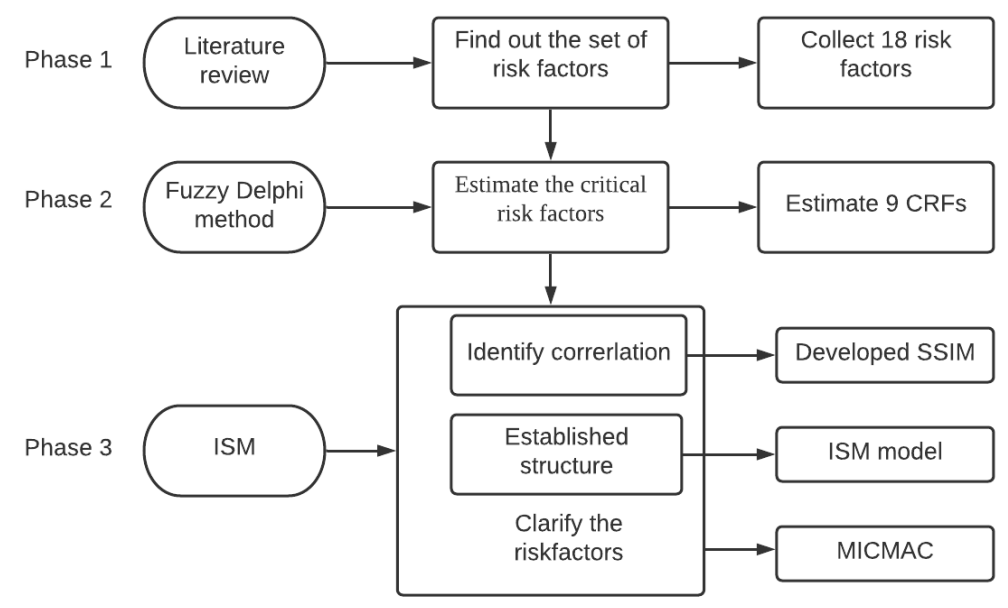

Figure 1. Study flow.

\subsection{Finalization of $C R F s$}

The identified eighteen risk factors as shown in Table 1 are further filtered to obtain CRFs, before ISM is carried out. One more reason is to filter risk factors is that ISM studies generally consider only fewer factors. This is due to an increase in the number of factors that increase the complexity of the method [101,102]. Therefore, we utilized the FDM to finalize the CRF's. Then after, the authors collected options from decision-makers by issuing questionnaire in telecommunication industry. The participants are asked to give on a scale of five points, i.e., strongly agree, agree flair, disagree, and strongly disagree for $1,2,3,4$ and 5 respectively. 30 questionnaires are sent to the decision-makers of different telecommunication companies and 21 valid responses ( $70 \%$ of response rate) are taken due to incomplete the responses.

The decision-makers are from public and private telecommunication companies as shown in Table 2. All of the experts have more than three years of experience in SCM at current companies and all have an average of more than ten years of experience in the telecommunication industry. Based on the expert's assessment, nine critical risk factors are determined based on the threshold value (0.65) of the FDM analysis as noted in Table 3, and the final nine CRFs are listed in Table 4.

Table 3. Fuzzy Delphi method result at threshold value 0.65.

\begin{tabular}{|c|c|c|}
\hline \multirow{2}{*}{ Risk Factor } & \multirow{2}{*}{ Defuzzification Value: $M I N+(4 \times$ Medium $)+M A X \backslash 6$} & \multirow{2}{*}{$\begin{array}{c}\text { Threshold } \\
0.65\end{array}$} \\
\hline & & \\
\hline R1 & 0.532945 & Delete \\
\hline $\mathrm{R} 2$ & 0.525414 & Delete \\
\hline R3 & 0.680404 & Accept \\
\hline $\mathrm{R} 4$ & 0.667895 & Accept \\
\hline $\mathrm{R} 5$ & 0.456772 & Delete \\
\hline R6 & 0.607943 & Delete \\
\hline $\mathrm{R} 7$ & 0.637821 & Accept \\
\hline R8 & 0.659291 & Accept \\
\hline $\mathrm{R} 9$ & 0.650842 & Accept \\
\hline R10 & 0.525414 & Delete \\
\hline R11 & 0.64603 & Accept \\
\hline R12 & 0.418285 & Delete \\
\hline R13 & 0.727303 & Accept \\
\hline R14 & 0.45958 & Delete \\
\hline R15 & 0.780826 & Accept \\
\hline R16 & 0.610639 & Delete \\
\hline R17 & 0.591402 & Delete \\
\hline R18 & 0.64603 & Accept \\
\hline
\end{tabular}


Table 4. Selected CRFs.

\begin{tabular}{ccc}
\hline S.no & Factor No. & CRFs \\
\hline 1 & R03 & Illegal activities (e.g., 2G Scams) \\
2 & R04 & Newly entering companies (e.g., Reliance JIO infocomm limited) \\
3 & R07 & Impact of rapid change of technology \\
4 & R08 & Lack of Telecom Infrastructure in semi-rural or rural areas \\
5 & R09 & Difficulty in import technology and process \\
6 & R11 & Change customer expectations \\
7 & R13 & Government policies (laws and regulations) \\
8 & R15 & Market competition \\
9 & R18 & Environmental pollution \\
\hline
\end{tabular}

\subsection{ISM Methodology}

ISM method, developed by Warfield in 1974, is an interactive learning method to recognize the direct and transitive relationships among the factors identified. There are few studies analyzing the factors with network structure model. In this model the relationship among factors is expressed in the form of pointers or links [103]. Instead, the hierarchical structure provides the relationship one factor from another factor in the network. Moreover, the ISM used to stratify each factor. In addition, there are few studies analyzing the risk factors with using ISM method. For example, Sun et al. [104] has applied ISM to analyze the risk factors of Building Information Modelling (BIM) technology implementation in the construction industry. In addition, identification of food safety risk factors was carried out by Zhang and Song [105]. In another study, analyzing the risk factors of public and private partnership (PPP) project in India [106]. In the telecommunications service industry, Raut et al. [107] have used ISM to study the key factors of strategic partnering for network-managed services [73] and to model the implementation barriers of cloud computing adoption. Pramod et al. [27], Talib, and Rahman [76] have used ISM to analyze the interrelationship among barriers in the Indian telecommunication industry. Furthermore, Bhadani et al. [77] have applied ISM integrated ANP for analyzing barriers in the telecom service adoption, but they also have conducted a survey within the Indian rural areas. Those studies do not provide the supply chain sustainability risk factors for the telecommunications sector. Then, this study adopted the ISM approach which developed by Al-Muftah et al. [108], and the process for executing the ISM method is outlined in Figure 2.

\subsubsection{Structural Self-Interaction Matrix (SSIM)}

After determining the nine CRFs by FDM result, the SSIM is developed with options of nine decision-makers from telecommunication service sector in Indian, and two researchers from academia, and the profile of experts as summarized in Table 5. The majority of them have more than two years in this filed. The SSIM have been developed based on the decision-makers consensus in the pairwise comparison of CRFs and Suresh et al. [109] using the following symbols:

$V:$ Factor $i$ influences/affects factor $j$

$A$ : Factor $j$ influences/affects factor $i$

$X$ : Factors $i$ and $j$ influences/affects each other

$O$ : Factor $i$ and $j$ have no relationship. 


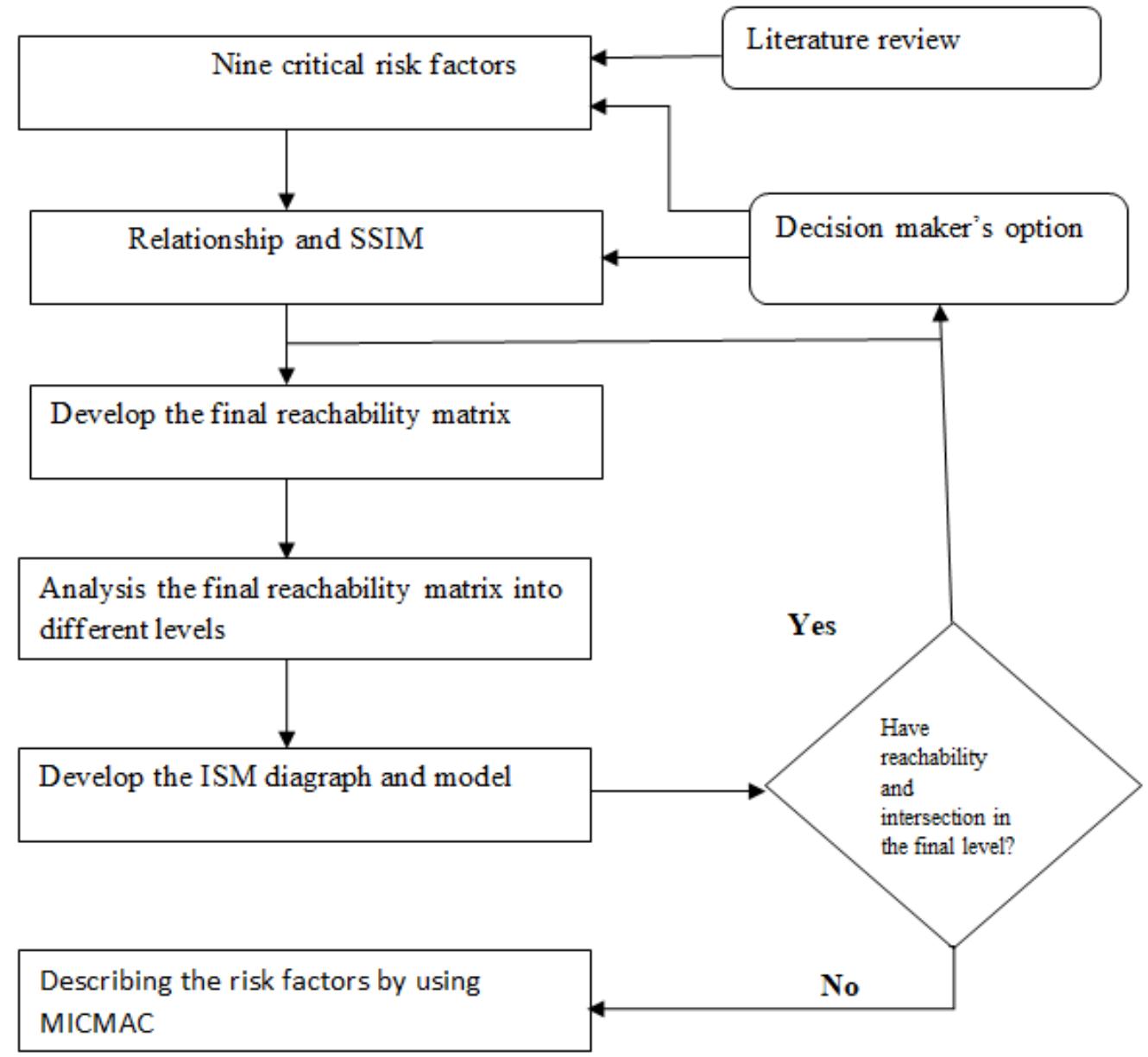

Figure 2. Process of executing ISM.

Table 5. Respondents' profile.

\begin{tabular}{cccccc}
\hline Decision Maker & Occupation & $\begin{array}{c}\text { Type of the } \\
\text { Company }\end{array}$ & Education & $\begin{array}{c}\text { Year(s) of } \\
\text { Work Experience in } \\
\text { the Present Company }\end{array}$ & $\begin{array}{c}\text { Year(s) of Work } \\
\text { Experience in the } \\
\text { Industry }\end{array}$ \\
\hline 1 & Manager & Private & Master & $>2$ Years & $>5$ Years \\
2 & Department Head & Private & Master & $>2$ Years & $>5$ Years \\
3 & Department Head & Public & Bachelor & $>2$ Years & $>5$ Years \\
4 & Manager & Public & Master & $<2$ Years & $>5$ Years \\
5 & Department Head & Public & Master & $>2$ Years & $>5$ Years \\
6 & Manager & Public & Master & $>2$ Years & $>5$ Years \\
7 & Manager & Private & Master & $<2$ Years & $>5$ Years \\
8 & Department Head & Private & Master & $<2$ Years & $>5$ Years \\
9 & Manager & Private & Bachelor & $>2$ Years & $>5$ Years \\
10 & Researcher & Private & Ph.D. & $>2$ Years & $>5$ Years \\
11 & Researcher & Private & Ph.D. & $>2$ Years & $>5$ Years \\
\hline
\end{tabular}

Row indicates factor $i$ and the column indicates factor $j$

For example, the risk factor R4 leads to risk factor R8 and so symbol $V$ has been placed in the cell $(2,5)$, while the risk factor R3 is affected by risk factor R8 and so symbol $A$ has been in the cell $(1,3)$. The contextual relationships of pair-wise comparison of CRFs relationships are captured in Table 6. 
Table 6. Structural Self-Interaction Matrix.

\begin{tabular}{cccccccccc}
\hline CFRs & R3 & R4 & R7 & R8 & R9 & R11 & R13 & R15 & R18 \\
\hline R3 & 1 & A & O & A & O & A & A & A & X \\
R4 & & 1 & X & V & X & V & A & V & O \\
R7 & & & 1 & V & X & V & A & V & V \\
R8 & & & & 1 & A & V & A & V & V \\
R9 & & & & & 1 & V & A & V & O \\
R11 & & & & & & 1 & A & V & O \\
R13 & & & & & & & 1 & V & V \\
R15 & & & & & & & & & V \\
R18 & & & & & & & & & \\
\hline
\end{tabular}

\subsubsection{Development of the Initial Reachability Matrix}

As the SSIM was obtained, then the symbols $(\mathrm{V}, \mathrm{A}, \mathrm{X}, \mathrm{O})$ in SSIM is converted into binary digits (i.e., $1 \mathrm{~s}$ or 0 s) matrix follow the rule listed in Table 7 , and the matrix is called the initial reachability matrix (IRM). For example, cell (R04, R11) in the SSIM is $V$, and the corresponding cell value in the IRM is 1 , and the (R11, R04) cell value is 0; cell (R04, R13) in the SSIM is $A$, and the corresponding cell value in the IRM is 0 , and the (R13, R04) cell value is 1 . All the symbols in SSIM were completely changed binary numbers of $0^{\prime} \mathrm{s}$ and $1^{\prime} \mathrm{s}$ as shown in Table 8. The IRM is developed to explain the relationship between each of the nine CRFs.

Table 7. The rule to convert the symbol in SSIM to IRM value.

\begin{tabular}{ccc}
\hline \multirow{2}{*}{$(\mathbf{i}, \mathbf{j})$ Values in SSIM } & \multicolumn{3}{c}{ Conversion Value in IRM } \\
\cline { 2 - 3 } & $(\mathbf{i}, \mathbf{j})$ & $\mathbf{( j ,}, \mathbf{i})$ \\
\hline V & 1 & 0 \\
A & 0 & 1 \\
X & 1 & 1 \\
O & 0 & 0 \\
\hline
\end{tabular}

Table 8. Initial Reachability Matrix.

\begin{tabular}{cccccccccc}
\hline \multirow{2}{*}{$\begin{array}{c}\text { Risk Factors } \\
\left(\mathbf{p}_{\mathbf{i}}\right)\end{array}$} & $\mathbf{R}$ 3 & $\mathbf{R} 4$ & $\mathbf{R 7}$ & $\mathbf{R} 8$ & $\mathbf{R 9}$ & $\mathbf{R} 11$ & $\mathbf{R} 13$ & $\mathbf{R} 15$ & $\mathbf{R} 18$ \\
\cline { 2 - 10 } R3 & 1 & 0 & 0 & 0 & 0 & 0 & 0 & 0 & 1 \\
R4 & 1 & 1 & 1 & 1 & 1 & 1 & 0 & 1 & 0 \\
R7 & 0 & 1 & 1 & 1 & 1 & 1 & 0 & 1 & 1 \\
R8 & 1 & 0 & 0 & 1 & 0 & 1 & 0 & 1 & 1 \\
R9 & 0 & 1 & 1 & 1 & 1 & 1 & 0 & 1 & 0 \\
R11 & 1 & 0 & 0 & 0 & 0 & 1 & 0 & 1 & 0 \\
R13 & 1 & 1 & 1 & 1 & 1 & 1 & 1 & 1 & 1 \\
R15 & 1 & 0 & 0 & 0 & 0 & 0 & 0 & 1 & 1 \\
R18 & 1 & 0 & 0 & 0 & 0 & 0 & 0 & 0 & 1 \\
\hline
\end{tabular}

\subsubsection{Establish Final Reachability Matrix}

The final reachability matrix (FRM) has been derived by incorporating the transitivity between the CRFs. The transitivity means that the contextual relation in which if factor $\mathrm{A}$ affects factor $B$ and factor $B$ affects factor $C$, and then factor $C$ will be affected by factor $A$. the transitivity measurement was computed by conducting a power iteration analysis. The final reachability matrix was obtained as depicted in Table 9. For example, factor R4 affects factor R3 and R3 affects factor R18, and then factor R18 is affected by factor R4. Thus, (R4, $\mathrm{R} 18$ ) is $1^{*}$, which means that there is a transitivity relationship between R4 (new entering companies) and R18 (government policies (laws and regulations)). 
Table 9. Final Reachability Matrix.

\begin{tabular}{|c|c|c|c|c|c|c|c|c|c|c|}
\hline \multirow{2}{*}{$\begin{array}{c}\text { Risk Factors } \\
\left(p_{i}\right)\end{array}$} & \multicolumn{9}{|c|}{ Risk Factors $\left(p_{j}\right)$} & \multirow{2}{*}{$\begin{array}{c}\text { Driving } \\
\text { Power }\end{array}$} \\
\hline & $\mathbf{R} 3$ & R4 & $\mathbf{R 7}$ & $\mathbf{R 8}$ & R9 & R11 & R13 & R15 & R18 & \\
\hline R3 & 1 & 0 & 0 & 0 & 0 & 0 & 0 & 0 & 1 & 2 \\
\hline $\mathrm{R} 4$ & 1 & 1 & 1 & 1 & 1 & 1 & 0 & 1 & $1^{*}$ & 8 \\
\hline R7 & $1^{*}$ & 1 & 1 & 1 & 1 & 1 & 0 & 1 & 1 & 8 \\
\hline R8 & 1 & 0 & 0 & 1 & 0 & 1 & 0 & 1 & 1 & 5 \\
\hline R9 & $1^{*}$ & 1 & 1 & 1 & 1 & 1 & 0 & 1 & $1^{*}$ & 8 \\
\hline R11 & 1 & 0 & 0 & 0 & 0 & 1 & 0 & 1 & $1^{*}$ & 4 \\
\hline R13 & 1 & 1 & 1 & 1 & 1 & 1 & 1 & 1 & 1 & 9 \\
\hline R15 & 1 & 0 & 0 & 0 & 0 & 0 & 0 & 1 & 1 & 3 \\
\hline R18 & 1 & 0 & 0 & 0 & 0 & 0 & 0 & 0 & 1 & 2 \\
\hline Dependence & 9 & 4 & 4 & 5 & 4 & 6 & 1 & 7 & 9 & 49 \\
\hline
\end{tabular}

Note: $1^{*}$ represents transitive link.

\subsubsection{Level Partitions}

The level partition contains two sets, viz. reachability set and antecedent set and this is derived from FRM. The reachability set includes each specific CRF from the respective rows, and the antecedent set contains each specific CRF from the respective column in the FRM. Then the intersection set is derived from the common factors of reachability and antecedent sets as Appendix A. in level partition, intersection factors are the only factors in the reachability set. These factors are removed from the list and are referred to as level-I factors. Then the procedure for obtaining CRFs is repeated in the next iteration and it does not stop until all the CRFs are placed in the ISM hierarchy. The interaction matrix functionality is presented in Table 10.

Table 10. Result of level partition iteration.

\begin{tabular}{ccccc}
\hline CRFS & $\begin{array}{c}\text { Reachability } \\
\left.\text { Set } \mathbf{R} \mathbf{( p}_{\mathbf{i}}\right)\end{array}$ & Antecedent Set $\mathbf{A}\left(\mathbf{p}_{\mathbf{i}}\right)$ & $\begin{array}{c}\text { Intersection Set } \\
\mathbf{R}\left(\mathbf{p}_{\mathbf{i}}\right) \cap \mathbf{A}\left(\mathbf{p}_{\mathbf{i}}\right)\end{array}$ & Level \\
\hline R3 & R3, R18 & R3, R4, R7, R8, R9, R11, R13, R15, R18 & R3, R18 & I \\
R4 & R4, R7, R9 & R4, R7, R9, R13 & R4, R7, R9 & V \\
R7 & R4, R7, R9 & R4, R7, R9, R13 & R4, R7, R9 & V \\
R8 & R8 & R4, R7, R8, R9, R13 & R8 \\
R9 & R4, R7, R9 & R4, R7, R9, R13 & R4, R7, R9 & V \\
R11 & R11 & R4, R7, R8, R9, R11, R13 & R11 & III \\
R13 & R13 & R13 & R13 & VI \\
R15 & R15 & R4, R7, R8, R9, R11, R13, R15 & II \\
R18 & R3, R18 & R3, R4, R7, R8, R9, R11, R13, R15, R18 & R3, R18 & I \\
\hline
\end{tabular}

\subsubsection{Build up Structural Model}

The final ISM based structural model of CRFs is constructed from level partition matrix as shown in Table 10 and the final reachability matrix is shown in Table 9. Based on the level partition matrix, draw the ISM digraph including nodes and transitivity links. Arrows between nodes show the direction of the influence. If factor i influences $j$, an arrow will point from i to j. For example, the risk factors "government policies (R13)" affects the risk factor "newly entering companies (R4)", so an arrow from R13 points to R4. Level I risk factors are placed at the top of the hierarchy and the least level risk factors are placed at the bottom of the hierarchy. Finally, a six levels hierarchy structure model includes nine CRFs is developed by removing the indirect links as depicted in Figure 3. 


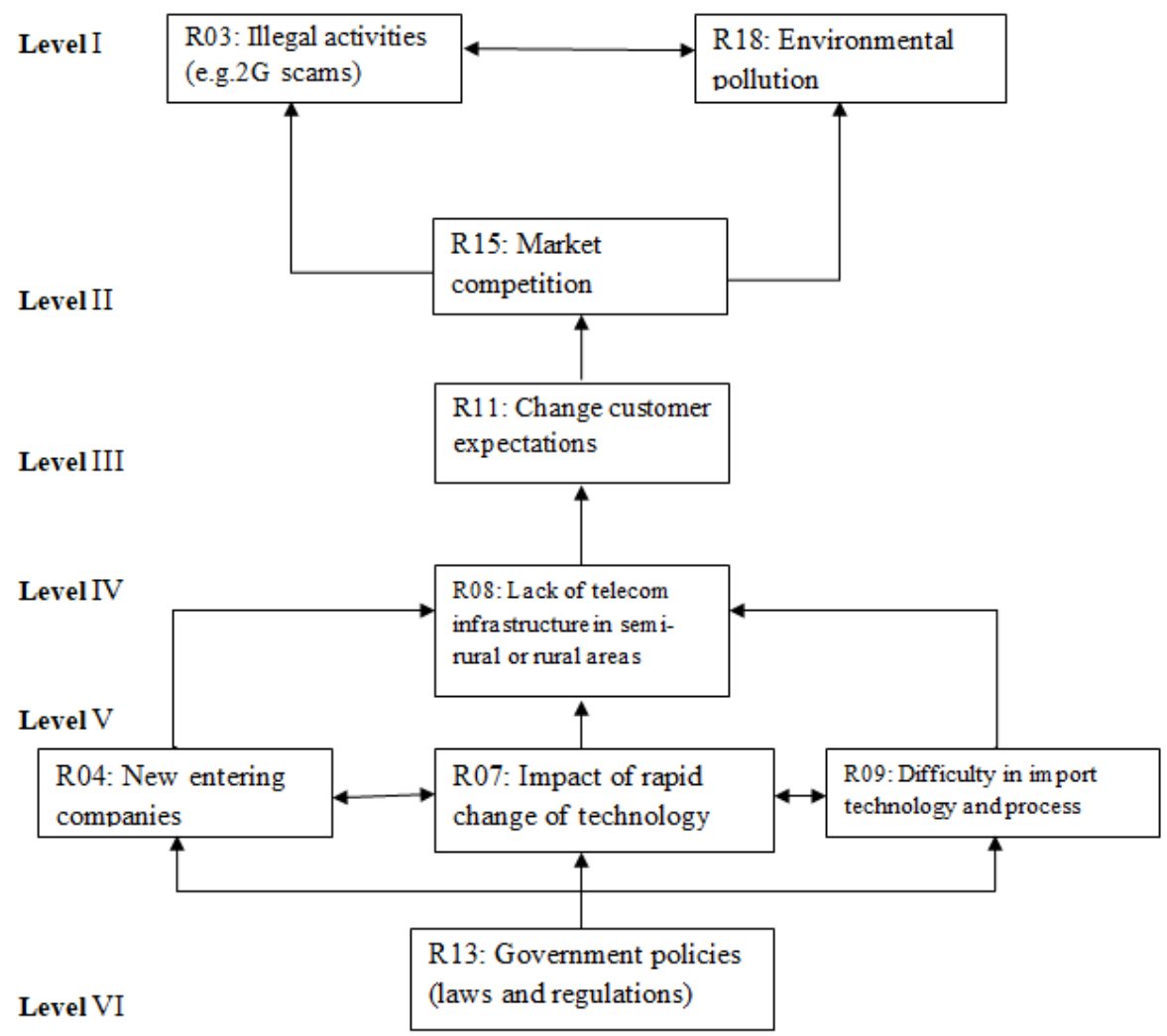

Figure 3. ISM model for CRFs of SSC of Indian telecommunication service.

The structure model illustrates the direct relations among CRFs, with arrows indicating the direction of each impact. Figure 3 shows that these nine CRFs are formed into six levels in the diagram. "illegal activities (e.g., 2G scam) (R3)" and "environmental pollution (R18)" are located at the top level, which directly depends on "market competition". Next "market competition" is affected by the CRF "change of customer expectations" which is located at the third level. Following, "Change of customer expectations" is impacted by the CRF "lack of telecom infrastructure in semi-rural or rural areas". Three CRFs "new entering companies (R4)", "impact of rapid change of technology (R7)", and "difficulty in import technology and process (R9)" resided at level V and affected each other, and ultimately affect the CRF "lack of telecom infrastructure in semi-rural or rural areas". Finally, the bottom-level CRF "government policies (laws and regulations) (R13)" which are considered a strong CRF and impact above levels CRFs. This means "government policies (laws and regulations)" is the decisive factors affecting the sustainability of the telecommunication service organization's supply chain in India.

\subsection{Categorizing Risk Factors Impacting SSC of Indian Telecommunication Service}

The categorization of CRFs that influence supply chain of telecommunications companies is carried out by applying the MICMAC method. MICMAC has been developed by Elmsalmi and Hachicha [110]. In addition, there are few studies conducted to analyze risk factors in the current literature. For example, Alora and Barua [100] had used MICMAC to disruption risk classification and prioritization of supply chain in India. And, another article classified risks prioritization in global supply networks using MICMAC method [111]. Jha et al. [112] carried out the research study identifying significant risks and analyzing risk relationship for construction PPP Projects in developing countries. Duperrin et al. [113] is modelling the risks in international projects by Indian construction companies. In addition, Chowdhury et al. [114] claim that the main aim of MICMAC analysis is to discover and evaluate each factor is driving power and dependence power. The "driving power" represents the degree of influence that one factor is affected by other 
factors. According to the driving power and dependence power, it is possible to set up a MICMAC diagram, with the horizontal axis denoting the degree of dependency and the vertical axis denoting the driving power [106]. The CRFs can be classified into four zones by using MICMAC, namely autonomous zone, dependent zone, linkage zone, and driver zone. Applying MICMAC analysis, the driving and dependence of CRFs of the supply chain in the telecommunications service industry in Table 9 were analyzed and ranked as listed in Table 11 and the MICMAC diagram was shown in Figure 4, which the nine CRFs can be classified into four zones based on their driving power and dependence power.

Table 11. The results of MICMAC ranking of CRFs.

\begin{tabular}{ccccc}
\hline CRFs & Driving Power & Dependence Power & Drive/Depend & MICMAC Rank \\
\hline R3 & 2 & 9 & 0.222 & 6 \\
\hline R4 & 8 & 4 & 2.000 & 2 \\
\hline R7 & 8 & 4 & 2.000 & 2 \\
\hline R8 & 5 & 5 & 1.000 & 3 \\
\hline R9 & 8 & 4 & 2.000 & 2 \\
\hline R11 & 4 & 6 & 0.667 & 4 \\
\hline R13 & 9 & 1 & 9.000 & 1 \\
\hline R15 & 3 & 7 & 0.429 & 5 \\
\hline R18 & 2 & 9 & 0.222 & 6 \\
\hline
\end{tabular}

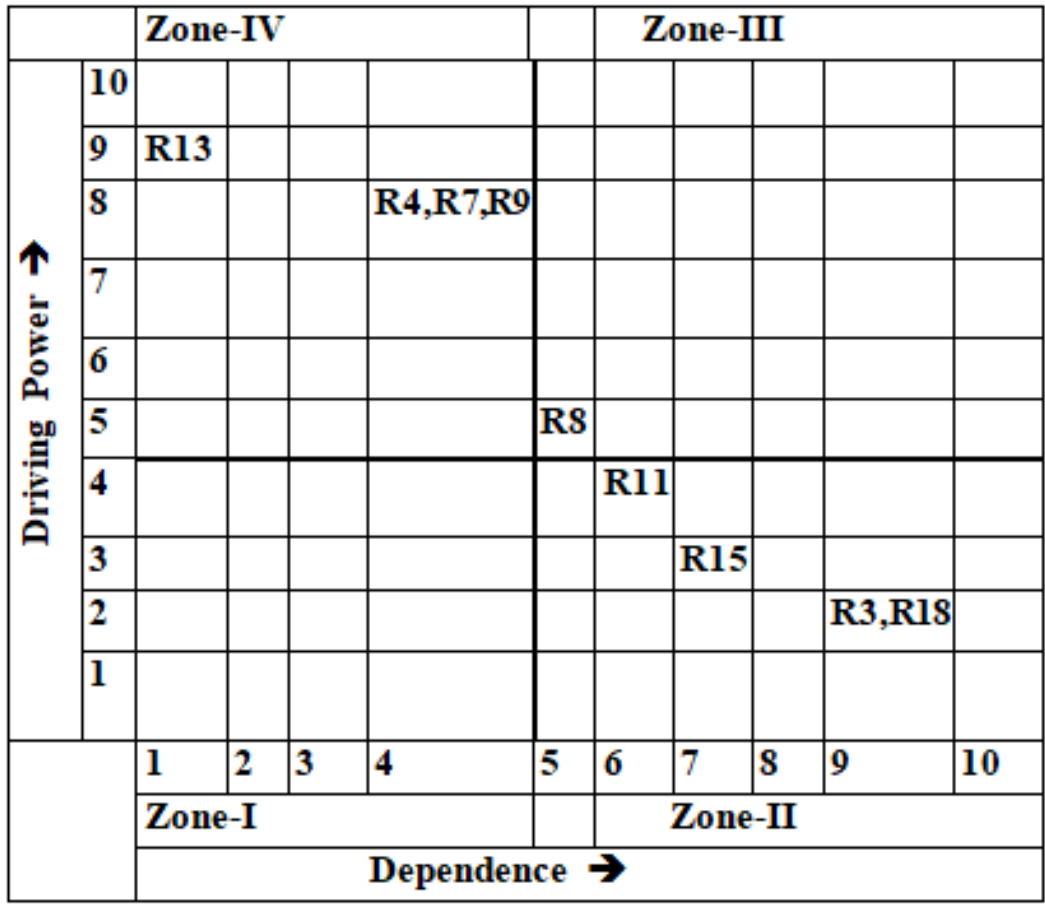

Figure 4. The results of MICMAC analysis of CRFs.

The MICMAC diagram shows in Figure 4 that no CRFs have been identified as autonomous variables. In addition, The R3, R11, R15, and R18 are identified in zone 2 as dependent variables. Where "Illegal activities (R3)" and "Environmental Pollution (R18)" possess the lowest driving power, but those CRFs have the highest dependence power and are at the top level of the ISM hierarchy as shown in Figure 3. Therefore, these CRFs can be determined as the minor affecting CRFs of sustainability in the supply chain, all the other CRFs are required to advance the dependent factors in enhancing the SSC system. In 
addition, the R8 is determined in zone 3 as a linkage variable. If we take, any action towards this factor may affect or influence the remaining CRFs. Finally, in zone 4 identified CRFs are R13, R4, R7, and R9 as the highest driving power variables. They are located at the bottom level of the ISM network as shown in Figure 3. This bottom level in ISM and zone 4 CRFs have the potential to affect the remaining CRFs, so the telecommunication companies should be given high priority to address them. These CRFs are very important and can be regarded as the focus of the management strategy by telecommunication decision-makers to achieve overall sustainability.

\section{Findings and Discussion}

Telecommunication sector has becoming much in the news due to its continuous development and has been an area of interaction for decision makers, academics, and researchers. They have analyzed the telecommunications industry as a platform, linking the country's informative-intensive ecosystem with its social and economic growth. In developing countries, the implementation of a set of risk-control policy is challenging at the government and organization levels. Moreover, the initiation of these policy and measures the risk is not an easy process and needs much analysis. The result of present study found that some of the potential CRF's have been highlighted and put into an ISM model, to analyze the interaction between them. These CRFs need to be addressed for the improvement in telecom services and hence, to the sector. In addition, the main objective of the present research is to identify and analyze the interrelationships between the various CRFs of SSC, which hinder the effective implementation of the supply chain, and to develop a hierarchy model of sustainable CRFs that help telecommunication companies to understand the influence relationship of these CRFs. There are few research tools available to calculate the weights and analyze the interrelationships. For example, the analytic network process (ANP) also derives the weights of the factors by comparing the criteria within a cluster to another cluster, but the important weight in ANP was subjective and assigned directly by experts. However, the important weight in ISM is more objective since it was derived from criteria influence relationships and matrix calculation. Unlike ANP, it was subjective and assigned directly by experts. These CRFs take on significance because they impede the sustainable implementation of the supply chain and pose significant challenges for managers and practitioners in telecommunication companies. The present study emphasizes the need to overcome these risk factors to gain sustainability in telecommunications companies in order to improve service quality and achieve greater customer satisfaction. From all the risk factors identified, the factor "government policies (laws and regulations)" is the most influential CRFs and it has been put at level six, while the risk factors "illegal activities (e.g., 2G scams)" and "market competition" are the least influential factors and they located in top of the model, as shown in Figure 3. We find that the risk factor "government policies (laws and regulations)", in line with prior research that demonstrates that it is the most significant risk factor in implementation of sustainability supply chain in telecommunication service $[9,64,115,116]$. However, the results showed that the risk factors illegal activities (R3)" and "environmental Pollution (R18)" are influenced by all factors and located at the top level as the target of the system. This results in contrast with other studies $[12,35,48]$, they have found that "illegal activities (e.g., 2G scams)" affects the stockholders' trust and Chapman and Corso [117] have found that "market competition" is also one of the most important factors in telecommunications supply chain.

Furthermore, according to the ISM hierarchy model of the current study, except the root cause factor "government policies (laws and regulations)", the CRFs at other levels support each other and influence to the next level of CRFs. A six level of hierarchy model has been established in the ISM in Figure 3. The dependence and driving power depicted in Figure 4 will provide valuable insights into the interdependence and relative importance of CRFs. In order to implement sustainable development standards in sustainable manner, the organizations need to determine the CRFs to be included within their strategic level. The current research emphasizes that supply chain practitioners and decision makers must 
keep these CRFs in mind while planning supply chain execution to enhance customer satisfaction and sustainable development.

\section{Managerial Implications}

In the present study, MICMAC analysis as shown in Figure 4 offers some insights into the relative significance and interdependencies among the CRFs. This would provide the top and middle-level management with valuable perspectives as they can efficiently handle these CRFs. The proposed ISM based framework for identifying the risk, it will offer a way to understand the interrelationship among CRFs to managers, and practitioners of SCM in the telecommunication companies. Telecommunication company's top management should be analyzed the more insights into the problem when implementing sustainability in their organization's [118]. Few of the ISM model observations, which indicate major managerial implications, which are as follows:

An important contribution of this research study is identifying and develops contextual relationships among CRFs for SSCMs through a systematic framework. The telecom managers can take specific steps to manage, control, and mitigate sustainable CRFs. Moreover, the application of the proposed ISM framework has implications for the complexity and order of the relationships among these CRFs, which would enable telecom managers and policymakers to achieve customer satisfaction with limited resources. The CRFs "government policies-laws and regulations (R13)", "new entering companies (R4)", "the impact of rapid change in technology (R7)", and "difficulty in import technology and process (R9)" are at the bottom to the middle level of the ISM hierarchy with high driving power and low dependence power. Based on the results, this study assumes that above four CRFs are most relevant major affecting factors in the telecommunication sector. Therefore, this valuable information could be help to telecommunication sector policymakers and managers to take flexible or transparent decisions, and it will assess their responsibility to addressing CRFs. The high driving power CRFs, they are the root cause of the occurrence of remaining CRFs in the ISM network. As per the hierarchy, most CRF is R13 (government policies-laws and regulations). R13 may affect the economic concerns and social aspects of SSCM because the implementation of government policies plays an important role in achieving the triple bottom line of sustainability $[6,35]$. Managers must periodically strengthen oversight and be aware of the government policies to achieve high standards of organizational performance to control sustainable risks. As it occurs at the sixth level of the ISM hierarchy model, telecommunication service operators must focus on the government implications and be willing to modify their organization's policies according to government policies and regulations to avoid the major risk. Moreover, this study results suggesting that the government should build justice, fairness, and open laws or regulations to all telecommunication companies for prevent major risk and to achieving overall sustainability. In addition, strategies and incorporate certain strategies to overcome high driving power CRFs for further development in the sector should be recommended. Furthermore, the factor lack of telecom infrastructure in semi-rural or rural area (R8)" and "market competition (R15)" are identified as linkage factors. It can conclude that this level CRFs are core factors since provides the only path to transform influences from the lower level to higher levels [56]. Thus, these factors should be continuously improved as they have an overall effect on all other CRFs. Therefore, it is suggested that the telecommunication companies need to monitor market competition and mitigate natural hazards through responses and sometimes by sharing and flexibility responses $[9,37]$. The results of this study indicate that the performance of telecom companies is influencing by government regulations as it affects systemic risk [27]. In addition, the research findings would be useful for regulators in framing new policies by taking into account the interests of both investors and customers, as the decisions of regulators can probably influence the systemic risk of the telecommunication firms. The telecom managers use this result to forest systemic risk level by calculating regulatory changes from the governments in developing countries $[58,69]$. The telecommunication managers should initiate training sections 
on government regulations and policies to educate service process channel members as well as customers and policymakers to overcome the sustainability issues and realize the importance of sustainability in the industry. From a theoretical perspective, an attempt has been made to identify nine CRFs and build the ISM network for the sustainable CRFs of the supply chain in telecommunication companies. Final emphasize, the risk creates interrelated and combined subsystem, and therefore, telecommunication managers should carefully examine and give highest priority to the most CRFs.

\section{Conclusions}

Sustainability has become a critical strategic problem in the telecommunication sector, in order to develop and stand out in the intense competition. Telecommunication organizations cannot adopt many sustainability developing practices with limited resources. In addition, scholars advocate that organizations should analyze the CRFs relationships and examine determinations for their implementation of sustainability practices. However, such an interaction evaluation has yet to be carried out adequately. This study has identified risk factors of sustainability in the supply chain through literature review and confirmed by telecom company decision makers, then after, finalized the CRFs by performed the fuzzy delphi method. In addition, this study aimed to develop a conceptual model on identified CRFs using ISM and MICMAC analysis for achieving sustainability in the supply chain of telecommunication companies, which are not expressed in the existing literature. Then, the interrelationships of the CRFs assessed by 11 decision-makers from telecommunication companies in India.

Based on ISM analysis results confirmed that the CRF "government policies (laws and regulations)" takes up the low level of the ISM model, while "illegal activities (e.g., $2 \mathrm{G}$ scam)" and "environmental pollution" are at the top level. Subsequently, this ISM approach is used to classify CRFs using MICMAC analysis based on their driving power and dependence power. This would guide the current telecommunication firms to control these CRFs, which would enable the supply chain to perform effective operations and achieve higher customer satisfaction by offering better services. As such, it empowers organizations to develop a pathway to excellence and long-term business strategy and to build sustainability strategy in different dimensions such as economic, social, environmental, and political. All the companies need to survive in strong industry competition; they need to develop significant capabilities to adopt market opportunities [35]. Companies in developing countries often do not change the dynamics of identifying CRFs. Therefore, these should improve their learning experience and, more importantly, capture the opportunities for change $[6,24]$. SCM managers at telecommunications companies help to improve the overall performance of the company and create a sustainable competitive advantage. Furthermore, this study results and proposed framework on CRFs of the supply chain may be helpful for providing effective services at high customer satisfaction and the current organizations develop an effective and long-term SSC strategy.

ISM and MICMAC techniques depict the contextual relationships between CRFs and identify the shortcomings that help policymakers and supply chain practitioners to reduce the vulnerability of the supply chain on decision-making and to maintain its sustainability [45]. This study would help to rule out these sustainable CRFs and find a new way to implement this in the existing telecommunications companies, especially in developing countries, that will contribute to the country's economy. It would also help to improve efficiency, save the resources of existing companies facing the challenges of sustainability improvement, and ultimately contribute to the economy of the country. Risk is a complex construct, and the present research does not look at every aspect of all the CFRs in telecom SSC. Another limitation of the study is that it focuses on developing countries, especially India. Therefore, it is difficult to determine to what extent the findings can be generalized to developed countries. Furthermore, the estimates of the IRM relationships of CRFs are based on the concessions of the experts' opinion that may increase the difficulty in decision-making by Jain and Banwet, 2013 [73]. In future research focuses on one specific 
area of operations in the industry. This outcome should not applicable to various sectors and developing countries. There is the probability that other sector may have influence relationship and ranking between the CRF's or, different process and service characteristics that could change resulting to different findings by using ISM method. It is suggested that the finding could be accurate if ISM is combined with Structural Equation Modelling (SEM), because ISM method is an exploratory study, the hierarchical structure was develop based on experts' influence assessment data and ISM analysis. The hierarchical structure model is not statistically validated. Thus, the result of hierarchical structure needs further confirmatory study to confirm it. So, we suggest the hierarchical structure model can be considered as SEM to examine the validity in future studies. The next alternative could be repetition of present study by using the total interpretive structural modelling (TISM) approach instead of ISM, which could be efficient for better understanding of interpretation among the identified CRF's. Finally, by merging DEMATEL and AHP, in order to explain and visualize the relationships of sustainability CRF's in the telecommunication services industry, the future scholars will understand the functional gaps of the ISM and DEMATEL approaches.

Author Contributions: Conceptualization: W.-K.C. and V.N. Methodology: C.-T.L. Writing-original draft preparation: W.-K.C., V.N. and S.M. Data collection: M.-M.L. Data analysis: W.-K.C., V.N., C.-T.L. and S.M. Review and editing: W.-K.C., V.N., S.M., M.-M.L. and C.-T.L. Validation: M.-M.L. and C.-T.L. All authors have read and agreed to the published version of the manuscript.

Funding: This research was funded by the Ministry of Science and Technology of Taiwan grant number MOST 108-2221-E-212-001-MY2.

Institutional Review Board Statement: Not applicable.

Informed Consent Statement: Informed consent was obtained from all subjects involved in the study.

Conflicts of Interest: The authors declare no conflict of interest.

\section{Appendix A}

Table A1. Partition matrix of itration-1.

\begin{tabular}{|c|c|c|c|c|}
\hline RFS & Reachability Set $\mathbf{R}\left(\mathrm{p}_{\mathbf{i}}\right)$ & Antecedent Set A $\left(p_{i}\right)$ & Intersection set $\mathbf{R}\left(\mathrm{p}_{\mathbf{i}}\right) \cap \mathbf{A}\left(\mathrm{p}_{\mathbf{i}}\right)$ & Level \\
\hline R3 & R3, R18 & R3, R4, R7, R8, R9, R11, R13, R15, R18 & R3, R18 & I \\
\hline R4 & R3, R4, R7, R8, R9, R11, R15, R18 & $\mathrm{R} 4, \mathrm{R} 7, \mathrm{R} 9, \mathrm{R} 13$ & R4, R7, R9 & \\
\hline R7 & R3, R4, R7, R8, R9, R11, R15, R18 & $\mathrm{R} 4, \mathrm{R} 7, \mathrm{R} 9, \mathrm{R} 13$ & R4, R7, R9 & \\
\hline R8 & R3, R 8, R11, R15, R18 & R4, R7, R8, R9, R13 & $\mathrm{R} 8$ & \\
\hline R9 & R3, R4, R7, R8, R9, R11, R15, R18 & R4, R7, R9, R13 & R4, R7, R9 & \\
\hline R11 & R3, R 11, R15, R18 & R4, R7, R8, R9, R11, R13 & R11 & \\
\hline R13 & $\begin{array}{c}\text { R3, R4, R7, R8, R9, R11, R13, R15, } \\
\text { R18 }\end{array}$ & R13 & R13 & \\
\hline R15 & R3, R15, R18 & R4, R7, R8, R9, R11, R13, R15 & $\mathrm{R} 15$ & \\
\hline R18 & R3, R 18 & R3, R4, R7, R8, R9, R11, R13, R15, R18 & R3, R18 & I \\
\hline
\end{tabular}

Table A2. Partition matrix of itration-2.

\begin{tabular}{|c|c|c|c|c|}
\hline CRFS & Reachability Set $\mathbf{R}\left(\mathrm{p}_{\mathbf{i}}\right)$ & Antecedent Set A ( $\left.p_{i}\right)$ & Intersection Set $\mathbf{R}\left(\mathrm{p}_{\mathbf{i}}\right) \cap \mathbf{A}\left(\mathrm{p}_{\mathbf{i}}\right)$ & Level \\
\hline $\mathrm{R} 4$ & R4, R7, R8, R9, R11, R15 & R4, R7, R9, R13 & R4, R7, R9 & \\
\hline R7 & R4, R7, R8, R9, R11, R15 & R4, R7, R9, R13 & $\mathrm{R} 4, \mathrm{R} 7, \mathrm{R} 9$ & \\
\hline $\mathrm{R} 8$ & R8, R11, R15 & $\mathrm{R} 4, \mathrm{R} 7, \mathrm{R} 8, \mathrm{R} 9, \mathrm{R} 13$ & R8 & \\
\hline R9 & R4, R7, R8, R9, R11, R15 & $\mathrm{R} 4, \mathrm{R} 7, \mathrm{R} 9, \mathrm{R} 13$ & R4, R7, R9 & \\
\hline R11 & R11, R15 & R4, R7, R8, R9, R11, R13 & $\mathrm{R} 11$ & \\
\hline R13 & R4, R7, R8, R9, R11, R13, R15 & R13 & R13 & \\
\hline $\mathrm{R} 15$ & $\mathrm{R} 15$ & R4, R7, R8, R9, R11, R13, R15 & $\mathrm{R} 15$ & II \\
\hline
\end{tabular}


Table A3. Partition matrix of itration-3.

\begin{tabular}{|c|c|c|c|c|}
\hline CRFS & Reachability Set R $\left(p_{i}\right)$ & Antecedent Set A $\left(p_{i}\right)$ & Intersection Set $R\left(p_{i}\right) \cap A\left(p_{i}\right)$ & Level \\
\hline $\mathrm{R} 4$ & R4, R7, R8, R9, R11 & R4, R7, R9, R13 & R4, R7, R9 & \\
\hline R7 & R4, R7, R8, R9, R11 & R4, R7, R9, R13 & $\mathrm{R} 4, \mathrm{R} 7, \mathrm{R} 9$ & \\
\hline $\mathrm{R} 8$ & $\mathrm{R} 8, \mathrm{R} 11$ & R4, R7, R8, R9, R13 & $\mathrm{R} 8$ & \\
\hline R9 & R4, R7, R8, R9, R11 & R4, R7, R9, R13 & R4, R7, R9 & \\
\hline R11 & $\mathrm{R} 11$ & $\mathrm{R} 4, \mathrm{R} 7,8,9,11,13$ & $\mathrm{R} 11$ & III \\
\hline R13 & R4, R7, R8, R9, R11, R13 & $\mathrm{R} 13$ & R13 & \\
\hline
\end{tabular}

Table A4. Partition matrix of itration-4.

\begin{tabular}{|c|c|c|c|c|}
\hline CRFS & Reachability Set $\mathbf{R}\left(\mathrm{p}_{\mathrm{i}}\right)$ & Antecedent Set A ( $\left.\mathrm{p}_{\mathrm{i}}\right)$ & Intersection Set $\mathbf{R}\left(\mathrm{p}_{\mathrm{i}}\right) \cap \mathbf{A}\left(\mathrm{p}_{\mathrm{i}}\right)$ & Level \\
\hline $\mathrm{R} 4$ & R4, R7, R8, R9 & $\mathrm{R} 4, \mathrm{R} 7, \mathrm{R} 9, \mathrm{R} 13$ & R4, R7, R9 & \\
\hline $\mathrm{R} 7$ & $\mathrm{R} 4, \mathrm{R} 7, \mathrm{R} 8, \mathrm{R} 9$ & $\mathrm{R} 4, \mathrm{R} 7, \mathrm{R} 9, \mathrm{R} 13$ & $\mathrm{R} 4, \mathrm{R} 7, \mathrm{R} 9$ & \\
\hline $\mathrm{R} 8$ & $\mathrm{R} 8$ & R4, R7, R8, R9, R13 & $\mathrm{R} 8$ & IV \\
\hline R9 & $\mathrm{R} 4, \mathrm{R} 7, \mathrm{R} 8, \mathrm{R} 9$ & R4, R7, R9, R13 & R4, R7, R9 & \\
\hline R13 & R4, R7, R8, R9, R13 & R13 & R13 & \\
\hline
\end{tabular}

Table A5. Partition matrix of itration-5.

\begin{tabular}{|c|c|c|c|c|}
\hline CRFS & Reachability Set $R\left(p_{i}\right)$ & Antecedent Set A $\left(p_{i}\right)$ & Intersection Set $R\left(p_{i}\right) \cap A\left(p_{i}\right)$ & Level \\
\hline $\mathrm{R} 4$ & R4, R7, R9 & R4, R7, R9, R13 & R4, R7, R9 & V \\
\hline R7 & R4, R7, R9 & R4, R7, R9, R13 & R4, R7, R9 & $\mathrm{V}$ \\
\hline R9 & R4, R7, R9 & $\mathrm{R} 4, \mathrm{R} 7, \mathrm{R} 9, \mathrm{R} 13$ & R4, R7, R9 & $\mathrm{V}$ \\
\hline R13 & R4, R7, R9, R13 & $\mathrm{R} 13$ & R13 & \\
\hline
\end{tabular}

Table A6. Partition matrix of itration-6.

\begin{tabular}{ccccc}
\hline CRFS & Reachability Set $\mathbf{R}\left(\mathrm{p}_{\mathbf{i}}\right)$ & Antecedent Set $\mathbf{A}\left(\mathrm{p}_{\mathbf{i}}\right)$ & Intersection Set $\mathbf{R}\left(\mathrm{p}_{\mathbf{i}}\right) \cap \mathbf{A}\left(\mathrm{p}_{\mathbf{i}}\right)$ & Level \\
\hline R13 & $\mathrm{R} 13$ & $\mathrm{R} 13$ & $\mathrm{R} 13$ & $\mathrm{VI}$ \\
\hline
\end{tabular}

\section{References}

1. Mishra, B.; Ghosh, S.; Kanjilal, K. Evaluation of import substitution strategy in Indian telecom sector: Empirical evidence of non-linear dynamics. Telecommun. Policy 2020, 44, 101998. [CrossRef]

2. Liu, C.; Jayakar, K. The evolution of telecommunications policy-making: Comparative analysis of China and India. Telecommun. Policy 2012, 36, 13-28. [CrossRef]

3. Athreya, M. India's telecommunications policy: A paradigm shift. Telecommun. Policy 1996, 20, 11-22. [CrossRef]

4. Baruah, P.; Baruah, R. Telecom Sector in India: Past, Present and Future. Int. J. Humanit. Soc. Sci. Stud. 2014, 1, 147-156.

5. Dokeniya, A. Re-forming the state: Telecom liberalization in India. Telecommun. Policy 1999, 23, 105-128. [CrossRef]

6. Song, W.; Ming, X.; Liu, H.-C. Identifying critical risk factors of sustainable supply chain management: A rough strength-relation analysis method. J. Clean. Prod. 2017, 143, 100-115. [CrossRef]

7. Svensson, G.; Wagner, B. Implementing and managing economic, social and environmental efforts of business sustainability. Manag. Environ. Qual. Int. J. 2015, 26, 195-213. [CrossRef]

8. Asimakopoulos, G.; Whalley, J. Market leadership, technological progress and relative performance in the mobile telecommunications industry. Technol. Forecast. Soc. Chang. 2017, 123, 57-67. [CrossRef]

9. Valinejad, F.; Rahmani, D. Sustainability risk management in the supply chain of telecommunication companies: A case study. J. Clean. Prod. 2018, 203, 53-67. [CrossRef]

10. Rezghdeh, K.; Shokouhyar, S. A six-dimensional model for supply chain sustainability risk analysis in telecommunication networks: A case study. Mod. Supply Chain Res. Appl. 2020, 2, 211-246. [CrossRef]

11. Kang, M.Y.; Choi, Y.; Choi, J. The effect of celebrity endorsement on sustainable firm value: Evidence from the Korean telecommunications industry. Int. J. Advert. 2019, 38, 563-576. [CrossRef] 
12. Gupta, P.; Jain, N. Signalling role of $2 \mathrm{G}$ scam investigation on stock market returns of select telecom companies in India. Int. J. Public Sect. Perform. Manag. 2019, 5, 370-383. [CrossRef]

13. Choi, T.-M.; Wallace, S.W.; Wang, Y. Risk management and coordination in service supply chains: Information, logistics and outsourcing. J. Oper. Res. Soc. 2016, 67, 159-164. [CrossRef]

14. Jain, R.K.; Gonela, S.K.; Bt, R. Telecom in India in 2017: Uncertainty Calling. Asian J. Manag. Cases 2020, 17, 147-168. [CrossRef]

15. Munyimi, T.F.; Chari, D.F.; Liu, S. The role of buyer-supplier relationships in achieving economic sustainability in the private telecommunication sector in Zimbabwe. Cogent Bus. Manag. 2018, 5, 1540917. [CrossRef]

16. Reichling, M.; Otto, T. The environmental impact of the new economy: Deutsche Telekom, telecommunications services and the sustainable future. In The Ecology of the New Economy; Routledge: Abingdon, UK, 2017; pp. 119-129. Available online: https:/ / www.taylorfrancis.com/chapters/environmental-impact-new-economy-markus-reichling-tim-otto/e/10.432 4/9781351282048-10 (accessed on 5 January 2021).

17. Ahmadi, H.B.; Petrudi, S.H.H.; Wang, X. Integrating sustainability into supplier selection with analytical hierarchy process and improved grey relational analysis: A case of telecom industry. Int. J. Adv. Manuf. Technol. 2017, 90, 2413-2427. [CrossRef]

18. Schoenherr, T.; Tummala, V.R.; Harrison, T.P. Assessing supply chain risks with the analytic hierarchy process: Providing decision support for the offshoring decision by a US manufacturing company. J. Purch. Supply Manag. 2008, 14, 100-111. [CrossRef]

19. Gouda, S.K.; Saranga, H. Sustainable supply chains for supply chain sustainability: Impact of sustainability efforts on supply chain risk. Int. J. Prod. Res. 2018, 56, 5820-5835. [CrossRef]

20. Ansari, Z.N.; Kant, R. A state-of-art literature review reflecting 15 years of focus on sustainable supply chain management. J. Clean. Prod. 2017, 142, 2524-2543. [CrossRef]

21. Naseem, K. Job stress, happiness and life satisfaction: The moderating role of emotional intelligence empirical study in telecommunication Sector Pakistan. J. Soc. Sci. Humanit. Stud. 2018, 4, 7-14. Available online: https://www.researchgate. net/profile/Khalida_Naseem2/publication/323165473_Job_Stress_Happiness_and_Life_Satisfaction_The_Moderating_ Role_of_Emotional_Intelligence_Empiri-cal_Study_in_Telecommunication_Sector_Pakistan/links/5a83b087a6fdcc6f3eb2 9728/Job-Stress-Happiness-and-Life-Satisfaction-The-Moderating-Role-of-Emotional-Intelligence-Empirical-Study-inTelecommunication-Sector-Pakistan.pdf (accessed on 5 January 2021).

22. Perlekar, N.; Thakkar, J.J. Risk management framework for outsourcing in the defence sector: A case from India. Int. J. Prod. Res. 2018, 57, 5892-5919. [CrossRef]

23. Eiser, J.R.; Bostrom, A.; Burton, I.; Johnston, D.M.; McClure, J.; Paton, D.; Van Der Pligt, J.; White, M.P. Risk interpretation and action: A conceptual framework for responses to natural hazards. Int. J. Disaster Risk Reduct. 2012, 1, 5-16. [CrossRef]

24. Seuring, S.; Müller, P.D.M. From a literature review to a conceptual framework for sustainable supply chain management. J. Clean. Prod. 2008, 16, 1699-1710. [CrossRef]

25. Giannarakis, G.; Litinas, N.; Theotokas, I. A Delphi Study to Identify Corporate Social Responsibility Indicators: The Case of Greek Telecommunication Sector. J. Sustain. Dev. 2011, 4, 16. [CrossRef]

26. Singh, B.; Grover, S.; Singh, V.; Chaudhary, P. Identification \& Analysis of gaps in service sector using ISM Approach. Int. J. Eng. Technol. Manag. Appl. Sci. 2015, 3, 205-209.

27. Pramod, V.R.; Banwet, D.K.; Sarma, P.R. Understanding the barriers of service supply chain management: An exploratory case study from Indian telecom industry. Opsearch 2015, 53, 358-374. [CrossRef]

28. Sahoo, T.; Banwet, D.K.; Momaya, K.S. Developing a Conceptual Framework for Strategic Technology Management Using ISM and MICMAC Methodology. Glob. Bus. Rev. 2010, 12, 117-143. [CrossRef]

29. Dyllick, T.; Hockerts, K. Beyond the business case for corporate sustainability. Bus. Strategy Environ. 2002, 11, 130-141. [CrossRef]

30. Ageron, B.; Gunasekaran, A.; Spalanzani, A. Sustainable supply management: An empirical study. Int. J. Prod. Econ. 2012, 140, 168-182. [CrossRef]

31. Gopalakrishnan, K.; Yusuf, Y.Y.; Musa, A.; Abubakar, T.; Ambursa, H.M. Sustainable supply chain management: A case study of British Aerospace (BAe) Systems. Int. J. Prod. Econ. 2012, 140, 193-203. [CrossRef]

32. Kumar, D.; Rahman, Z. Buyer supplier relationship and supply chain sustainability: Empirical study of Indian automobile industry. J. Clean. Prod. 2016, 131, 836-848. [CrossRef]

33. Manuj, I.; Mentzer, J.T. Global supply chain risk management strategies. Int. J. Phys. Distrib. Logist. Manag. 2008, 38, 192-223. [CrossRef]

34. Lessard, D. Uncertainty and Risk in Global Supply Chains. SSRN Electron. J. 2013. [CrossRef]

35. Giannakis, M.; Papadopoulos, T. Supply chain sustainability: A risk management approach. Int. J. Prod. Econ. 2016, 171, 455-470. [CrossRef]

36. Diabat, A.; Govindan, K.; Panicker, V.V. Supply chain risk management and its mitigation in a food industry. Int. J. Prod. Res. 2012, 50, 3039-3050. [CrossRef]

37. Sharma, S.K.; Bhat, A.K. Supply chain risk management dimensions in Indian automobile industry. Benchmarking Int. J. 2014, 21, 1023-1040. [CrossRef]

38. Govindan, K.; Soleimani, H.; Kannan, D. Reverse logistics and closed-loop supply chain: A comprehensive review to explore the future. Eur. J. Oper. Res. 2015, 240, 603-626. [CrossRef]

39. Esfahbodi, A.; Zhang, Y.; Watson, G. Sustainable supply chain management in emerging economies: Trade-offs between environmental and cost performance. Int. J. Prod. Econ. 2016, 181, 350-366. [CrossRef] 
40. Luthra, S.; Garg, D.; Haleem, A. An analysis of interactions among critical success factors to implement green supply chain management towards sustainability: An Indian perspective. Resour. Policy 2015, 46, 37-50. [CrossRef]

41. Dubey, R.; Gunasekaran, A.; Papadopoulos, T.; Childe, S.J.; Shibin, K.T.; Wamba, S.F. Sustainable supply chain management: Framework and further research directions. J. Clean. Prod. 2017, 142, 1119-1130. [CrossRef]

42. Talib, F.; Rahman, Z.; Qureshi, M.N. Identifying the key practices of TQM in Indian Service Industries: An empirical analysis. In Proceedings of the International Conference on Advances in Supply Chain and Manufacturing Management (ASCMM 2011), Kharagpur, India, 16-18 December 2011; Available online: https:/ / ssrn.com/abstract=2729826 (accessed on 5 January 2021).

43. Rao, S.S. Social development in Indian rural communities: Adoption of telecentres. Int. J. Inf. Manag. 2008, 28, 474-482. [CrossRef]

44. Ray, P.K.; Ray, S. Resource-Constrained Innovation for Emerging Economies: The Case of the Indian Telecommunications Industry. IEEE Trans. Eng. Manag. 2009, 57, 144-156. [CrossRef]

45. Pramod, V.R.; Banwet, D.K. System modelling of telecom service sector supply chain: A SAP-LAP analysis. Int. J. Bus. Excel. 2010, 3, 38. [CrossRef]

46. Sehgal, V.; Sagar, M.; Shankar, R. Modelling of Key Success Factors for Mobile Virtual Network Operators in Indian Telecommunication Market. Glob. Bus. Rev. 2016, 17, 1314-1338. [CrossRef]

47. Luo, Z.; Dubey, R.; Papadopoulos, T.; Hazen, B.; Roubaud, D. Explaining Environmental Sustainability in Supply Chains Using Graph Theory. Comput. Econ. 2017, 52, 1257-1275. [CrossRef]

48. Gangotra, A.; Shankar, R. Strategies in managing risks in the adoption of business analytics practices: A case study of a telecom service provider. J. Enterp. Inf. Manag. 2016, 29, 374-399. [CrossRef]

49. Thakur, R.; Srivastava, M. Customer usage intention of mobile commerce in India: An empirical study. J. Indian Bus. Res. 2013, 5, 52-72. [CrossRef]

50. Pramod, V.R.; Banwet, D.K. Analytic Network Process Analysis of an Indian Telecommunication Service Supply Chain: A Case Study. Serv. Sci. 2010, 2, 281-293. [CrossRef]

51. Yadav, N. Total interpretive structural modelling (TISM) of strategic performance management for Indian telecom service providers. Int. J. Prod. Perform. Manag. 2014, 63, 421-445. [CrossRef]

52. Vidyarthi, R.; Singh, D. Clustering Value Drivers of Indian Telecom Customers-Pathway for Effective Strategy Formulation. Glob. J. Flex. Syst. Manag. 2011, 12, 53-63. [CrossRef]

53. De Brentani, U. Success Factors in Developing New Business Services. Eur. J. Mark. 1991, 25, 33-59. [CrossRef]

54. Kaur, B.P.; Aggarwal, H. Information system implementation failures in Indian telecommunication companies. Int. J. Indian Cult. Bus. Manag. 2015, 10, 84. [CrossRef]

55. Das, D. The impact of Sustainable Supply Chain Management practices on firm performance: Lessons from Indian organizations. J. Clean. Prod. 2018, 203, 179-196. [CrossRef]

56. Chaudhuri, A.; Srivastava, S.K.; Srivastava, R.K.; Parveen, Z. Risk propagation and its impact on performance in food processing supply chain. J. Model. Manag. 2016, 11, 660-693. [CrossRef]

57. Yan, M.-R.; Chien, K.-M.; Yang, T.-N. Green Component Procurement Collaboration for Improving Supply Chain Management in the High Technology Industries: A Case Study from the Systems Perspective. Sustainability 2016, 8, 105. [CrossRef]

58. Kour, M.; Chaudhary, K.; Singh, S.; Kaur, B. A Study on Impact of GST after its Implementation. Int. J. Innov. Stud. Sociol. Humanit. 2016, 1, 17-24. Available online: http://ijissh.org/wp-content/uploads/2017/01/IJISSET-010204.pdf (accessed on 5 January 2021).

59. Bhattacharya, S.; Mukhopadhyay, D.; Giri, S. Supply chain management in Indi-an automotive industry: Complexities, challenges and way ahead. Int. J. Manag. Value Supply Chain. 2014, 5, 49. Available online: http://www.academia.edu/download/57926713 /5214ijmvsc06.pdf (accessed on 5 January 2021). [CrossRef]

60. Foreman, R. A logistic analysis of bankruptcy within the US local telecommunications industry. J. Econ. Bus. 2003, 55, 135-166. [CrossRef]

61. Dani, S. A Research Paper on an Impact of Goods and Service Tax (GST) on Indian Economy. Bus. Econ. J. 2016, 7, 1-2. [CrossRef]

62. Miri-Lavassani, K. Coopetition and sustainable competitiveness in business ecosystem: A networks analysis of the global telecommunications industry. Transnatl. Corp. Rev. 2017, 9, 281-308. [CrossRef]

63. Arawomo, O.; Apanisile, J.F. Determinants of Foreign Direct Investment in the Nigerian Telecommunication Sector. Mod. Econ. 2018, 9, 907-923. [CrossRef]

64. Hofmann, H.; Busse, C.; Bode, C.; Henke, M. Sustainability-Related Supply Chain Risks: Conceptualization and Management. Bus. Strat. Environ. 2014, 23, 160-172. [CrossRef]

65. Osabutey, E.L.C.; Okoro, C. Political Risk and Foreign Direct Investment in Africa: The Case of the Nigerian Telecommunications Industry. Thunderbird Int. Bus. Rev. 2015, 57, 417-429. [CrossRef]

66. Mukherji, R. The Politics of Telecommunications Regulation: State-Industry Alliance Favouring Foreign Investment in India. J. Dev. Stud. 2008, 44, 1405-1423. [CrossRef]

67. Masson, S.; Jain, R.; Ganesh, N.M.; George, S.A. Operational efficiency and service delivery performance: A comparative analysis of Indian telecom service providers. Benchmarking Int. J. 2016, 23, 893-915. [CrossRef]

68. Singh, R. Impact of Reliance JIO on Indian Telecom Industry: An empirical study. Int. J. Sci. Res. Manag. 2017, 5, 6469-6474. [CrossRef]

69. Raju, R.; Madhuri, G. Vodafone and Idea Merger: A Shareholder's Dilemma. Glob. Bus. Rev. 2020. [CrossRef] 
70. Kaur, J. A case study on market leaders and challengers of the Indian telecom industry (mobile phone segment) with special reference to reliance JIO's strategies and performance challenging existing firms. J. Res. Bede Athenaeum 2018, 9, 44. [CrossRef]

71. Mishra, K.; Tarannum, A. Impact of Reliance Jio on Indian Telecom Industry. Acad. J. Account. Financ. 2019, 1, 25-29. [CrossRef]

72. Aggarwal, R. The Fama-French Three Factor Model and the Capital Asset Pricing Model: Evidence from the Indian Stock Market. Indian J. Res. Cap. Mark. 2017, 4, 36. [CrossRef]

73. Jain, D.; Banwet, D. Modelling critical elements of selection for strategic alliance partner for network managed services using interpretive structural modelling (ISM). J. Model. Manag. 2013, 8, 290-304. [CrossRef]

74. Kittilaksanawong, W.; Kandaswamy, S. Vodafone-Idea merger: Emergence of a telecom giant amidst predatory price wars. CASE J. 2018, 14, 609-634. [CrossRef]

75. Singh, S.B. Mergers and Acquisitions in the Telecom Industry. J. Commer. Econ. Manag. 2018, 2, 18-27. Available online: http:/ / management.nrjp.co.in/index.php/JCEM/article/download/194/475 (accessed on 5 January 2021).

76. Talib, F.; Rahman, Z. Modeling the barriers of Indian telecom services using ISM and MICMAC approach. J. Asia Bus. Stud. 2017, 11, 188-209. [CrossRef]

77. Bhadani, A.; Shankar, R.; Rao, D.V. Modeling the barriers of service adoption in rural Indian telecom using integrated ISM-ANP. J. Model. Manag. 2016, 11, 2-25. [CrossRef]

78. Agrell, P.J.; Lindroth, R.; Norrman, A. Risk, information and incentives in telecom supply chains. Int. J. Prod. Econ. 2004, 90, 1-16. [CrossRef]

79. Gupta, R.; Jain, K. Diffusion of mobile telephony in India: An empirical study. Technol. Forecast. Soc. Chang. 2012, 79, 709-715. [CrossRef]

80. Colicchia, C.; Creazza, A.; Noè, C.; Strozzi, F. Information sharing in supply chains: A review of risks and opportunities using the systematic literature network analysis (SLNA). Supply Chain Manag. Int. J. 2019, 24, 5-21. [CrossRef]

81. Rogers, H.; Srivastava, M.; Pawar, K.S.; Shah, J. Supply chain risk management in India-practical insights. Int. J. Logist. Res. Appl. 2015, 19, 278-299. [CrossRef]

82. Xavier, P.; Ypsilanti, D. Geographically segmented regulation for telecommunications: Lessons from experience. Info 2011, 13, 3-18. [CrossRef]

83. Wagner, S.M.; Bode, C. An empirical examination of supply chain performance along several dimensions of risk. J. Bus. Logist. 2008, 29, 307-325. [CrossRef]

84. Nayak, A. Internationalisation of the Indian telecommunication industry (1947-2004): A firm-level perspective. Bus. Hist. 2021, 63, 52-71. [CrossRef]

85. Lee, K.; Mani, S.; Mu, Q. Explaining divergent stories of catch-up in the telecommunication equipment industry in Brazil, China, India, and Korea. Econ. Dev. Learn. Process 2012, 21-71. [CrossRef]

86. Narayana, M. Telecommunications services and economic growth: Evidence from India. Telecommun. Policy 2011, 35, 115-127. [CrossRef]

87. Mohammed, W.F.; Xiao, A.; Hilton, E. A Critical Analysis of Corporate Social Responsibility in Ghana's Telecommunications Industry. Communicatio 2019, 45, 4-22. [CrossRef]

88. Runhaar, H.; Lafferty, H. Governing Corporate Social Responsibility: An Assessment of the Contribution of the UN Global Compact to CSR Strategies in the Telecommunications Industry. J. Bus. Ethics 2008, 84, 479-495. [CrossRef]

89. Sarker, F.H. Corporate Social Responsibility of Telecom Industries in Bangladesh: Rhetoric vs. Realities. Soc. Sci. $2014,3,199$. [CrossRef]

90. Sharma, S.; Sinha, A. Qualitative gap analysis of telecommunication industry's corporate social responsibility over ecological dimension. J. Organ. Hum. Behav. 2017, 6. Available online: https:/ / ssrn.com/abstract=2991258 (accessed on 5 January 2021).

91. Kodua, P.; Mensah, P. The Role of Corporate Social Responsibility in Influencing Brand Loyalty: Evidence from the Ghanaian Telecommunication Industry. In Marketing at the Confluence between Entertainment and Analytics; Springer: Cham, Switzerland, 2017; pp. 77-90. [CrossRef]

92. Petrazzini, B.A. Telecommunications policy in India: The political underpinnings of reform. Telecommun. Policy 1996, $20,39-51$. [CrossRef]

93. Pournader, M.; Rotaru, K.; Kach, A.P.; Hajiagha, S.H.R. An analytical model for system-wide and tier-specific assessment of resilience to supply chain risks. Supply Chain Manag. Int. J. 2016, 21, 589-609. [CrossRef]

94. Pence, J. Towards a new telecommunications industry quality standard. Proc. IEEE 1993, 81, 166-180. [CrossRef]

95. Meena, J.K.; Verma, A.; Kohli, C.; Ingle, G.K. Mobile phone use and possible cancer risk: Current perspectives in India. Indian J. Occup. Environ. Med. 2016, 20, 5-9. [CrossRef] [PubMed]

96. Gupta, S.; Tyagi, K.; Upadhyay, R. Twilight of voice, dawn of data: The future of telecommunications in India. Decision 2018, 45, 161-183. [CrossRef]

97. Jüttner, U.; Peck, H.; Christopher, M. Supply chain risk management: Outlining an agenda for future research. Int. J. Logist. Res. Appl. 2003, 6, 197-210. [CrossRef]

98. Jones, S.; Oven, K.J.; Wisner, B. A comparison of the governance landscape of earthquake risk reduction in Nepal and the Indian State of Bihar. Int. J. Disaster Risk Reduct. 2016, 15, 29-42. [CrossRef]

99. Krzemień, A.; Sánchez, A.S.; Fernández, P.R.; Zimmermann, K.; Coto, F.G. Towards sustainability in underground coal mine closure contexts: A methodology proposal for environmental risk management. J. Clean. Prod. 2016, 139, 1044-1056. [CrossRef] 
100. Alora, A.; Barua, M.K. An integrated structural modelling and MICMAC analysis for supply chain disruption risk classification and prioritisation in India. Int. J. Value Chain Manag. 2019, 10, 1-25. [CrossRef]

101. Attri, R.; Dev, N.; Sharma, V. Interpretive structural modelling (ISM) ap-proach: An overview. Res. J. Manag. Sci. 2013, $2319,1171$. Available online: https://www.researchgate.net/profile/Mohamed_Mourad_Lafifi/post/What_is_the_need_to_incorporate_ transitivity_in_ISM/attachment/59d63a0679197b8077997374/AS:404328411090949@1473410813877/download/Interpretive+ Structural+Modelling+\%28ISM\%29+approach+On+Overview+2.ISCA-RJMS-2012-054.pdf (accessed on 5 January 2021).

102. Tan, T.; Chen, K.; Xue, F.; Lu, W. Barriers to Building Information Modeling (BIM) implementation in China's prefabricated construction: An interpretive structural modeling (ISM) approach. J. Clean. Prod. 2019, 219, 949-959. [CrossRef]

103. Rana, N.P.; Barnard, D.J.; Baabdullah, A.M.; Rees, D.; Roderick, S. Exploring barriers of m-commerce adoption in SMEs in the UK: Developing a framework using ISM. Int. J. Inf. Manag. 2019, 44, 141-153. [CrossRef]

104. Raut, R.D.; Priyadarshinee, P.; Jha, M.; Gardas, B.B.; Kamble, S. Modeling the implementation barriers of cloud computing adoption. Benchmarking Int. J. 2018, 25, 2760-2782. [CrossRef]

105. Sun, C.; Xu, H.; Jiang, S. Understanding the risk factors of BIM technology implementation in the construction industry: An interpretive structural modeling (ISM) approach. Eng. Constr. Arch. Manag. 2020, 27, 3289-3308. [CrossRef]

106. Zhang, Y.; Song, Y. Identification of food safety risk factors based on intelli-gence flow and DEMATEL-ISM (DEcision-MAking Trial and Evaluation Laboratory and Interpretative Structural Modeling). DYNA-Ing. Ind. 2020, 95, 418-424.

107. Wenqin, L.; Yuanru, S. Risk factors analysis of PPP project of pension agency based on ISM. In Proceedings of the 2017 3rd International Conference on Information Management (ICIM), Chengdu, China, 21-23 April 2017; pp. 51-55.

108. Al-Muftah, H.; Weerakkody, V.; Rana, N.P.; Sivarajah, U.; Irani, Z. Factors in-fluencing e-diplomacy implementation: Exploring causal relationships using interpretive structural modelling. Gov. Inf. Q. 2018, 35, 502-514. [CrossRef]

109. Suresh, M.; Nathan, R.A.R. Readiness for lean procurement in construction projects. Constr. Innov. 2020, 20, 587-608. [CrossRef]

110. Elmsalmi, M.; Hachicha, W.; Hachicha, W. Risks prioritization in global supply networks using MICMAC method: A real case study. In Proceedings of the 2013 International Conference on Advanced Logistics and Transport, Sousse, Tunisia, 29-31 May 2013; pp. 394-399.

111. Jiang, X.; Lu, K.; Xia, B.; Liu, Y.; Cui, C. Identifying Significant Risks and Analyzing Risk Relationship for Construction PPP Projects in China Using Integrated FISM-MICMAC Approach. Sustainability 2019, 11, 5206. [CrossRef]

112. Jha, K.N.; Devaya, M.N. Modelling the risks faced by Indian construction companies assessing international projects. Constr. Manag. Econ. 2008, 26, 337-348. [CrossRef]

113. Duperrin, J.-C.; Godet, M. Méthode de hiérarchisation des éléments d'un sys-tème: Essai de prospective du système de l'énergie nucléaire dans son contexte sociétal. 1973. Available online: https://hal-lara.archives-ouvertes.fr/hal-02185432/ (accessed on 5 January 2021).

114. Chowdhury, N.A.; Ali, S.M.; Mahtab, Z.; Rahman, T.; Kabir, G.; Paul, S.K. A structural model for investigating the driving and dependence power of supply chain risks in the readymade garment industry. J. Retail. Consum. Serv. 2019, 51, 102-113. [CrossRef]

115. Ratnasingam, P. Perceived Risks in Supply Chain Management E-Collaboration. J. Internet Commer. 2006, 5, 105-124. [CrossRef]

116. Closs, D.J.; Speier, C.; Meacham, N. Sustainability to support end-to-end value chains: The role of supply chain management. J. Acad. Mark. Sci. 2010, 39, 101-116. [CrossRef]

117. Corso, M. From continuous improvement to collaborative innovation: The next challenge in supply chain management. Prod. Plan. Control. 2005, 16, 339-344. [CrossRef]

118. Mishra, A.; Kumar, D.; Shuaib, M.; Tyagi, M.; Singh, R.P. Measurement of Crit-ical Factors: A Case of Telecommunication Industry. In Operations Management and Systems Engineering; Springer: Singapore, 2019; pp. 259-274. 